\title{
上㴿洞慢性副鼻腔炎根治手術の臨床統計
}

\author{
飯島 直也・石山 哲也・田口喜一郎

\section{Radical Surgery for Chronic Maxillary Sinusitis} \\ Naoya Iijima, Tetsuya Ishiyama and Kiichiro Taguchi \\ (Shinshu University School of Medicine)
}

\begin{abstract}
We investigated 108 cases of radical surgery for chronic maxillary sinusitis from 1989 to 1997. The number of cases, sex, age, chief complaint, and clinical history were reviewed.

On average 12 cases of the operation was performed in a year. The male to female ratio was about $3: 2$. The most important chief complaints were nasal obstruction and nasal discharge. The average suffering period was about 5 years, while $27 \%$ of the patients suffered for over 10 years. Our policy is to perform radical surgery only on patients suffering from sinusitis who were junior high school age (12 years old) and older.
\end{abstract}

Key words : radical operation, chronic maxillary sinusitis

はじめに

食生活ならびに公衆衛生の向上执よび，主にマクロラ イド采抗生物質使用法の発達により, 慢性副鼻腔炎症例 の減少, 軽症化がいわれているが，耳鼻咽喉科領域では いまだに最も多い慢性炎症疾患の一つで手術症例も少な くない.

今回，当院耳鼻咽喉科に捛いて平成年間 ( 9 年間)に上 顎洞根本術を行った108例に臨床的検討を行い若干の文 献的考察を試みたのでその大要を報告する.$$
\text { 対 象 }
$$

平成元年から平成 9 年までの 9 年間に信州大学耳鼻咽 喉科にて上㴿洞根本手術を行った108例である(図 1 ). 年齢分布は $12 \sim 72$ 歳であり, 男性 68 人 (12 72歳, 平均 43 歳)女性 40 人 (13 72歳, 平均 40 歳) で全体として, 平 均年齢は 42 歳であった。な拈上罘洞悪性腫瘍に対する手 術症例は除外した。
}

調整事項は, 年度別手術数, 副鼻腔真菌症例, 初発症 状からの期間，主訴の分類，18歳以下の症例につき検討 を加えた。

\author{
結果 \\ 1. 年度別症例数 \\ 平成元年度は24例と多いが，拈拈むね 10 例前後手術を \\ 行っている. 平均12例である. 図 2 に示す. \\ 2 . 慢性副鼻腔炎以外の症例 \\ 上咢洞真菌症が 3 例存在した. 表 1 と示す. 平成元, \\ 3,7 年において各 1 例ずつ施行された(表 1 ). \\ 3 . 症状発現時より手術までの期間 \\ 症状発現時点より手術時までの期間を調査し得た症例 \\ は 75 人でその結果を図 3 に示す．平均は 5.4 年で，10年 \\ 以上要しているものも (31\%)存在した(図 3 ). \\ 4. 主訴の分類 \\ 主訴の明らかな83例に捻いて，複数の訴えを示すもの \\ はそれぞれの項目別に算出した，鼻閉55例 (66\%)，鼻汁 \\ 31 例 (37\%), 無臭症 6 例 ( $7 \%$ ), 頭痛 4 例 ( $5 \%$ )であっ \\ た(図 4 ). \\ 5. 中高生に扣いての根治手術症例 \\ 平均罹患期間は 5 年, 鼻閉は全例に認められた (表 2 ).
}




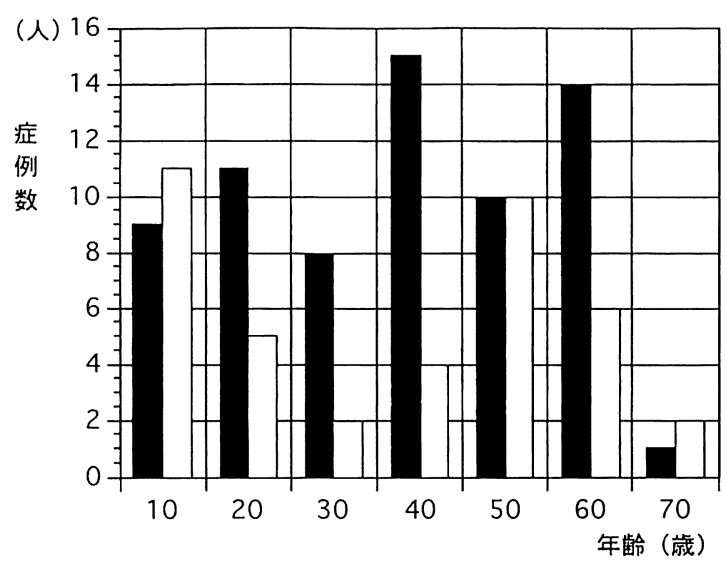

\section{\begin{tabular}{|l}
$\square$ 男 \\
$\square$ 女
\end{tabular}}

図 1 性別扣よび年㱓分布

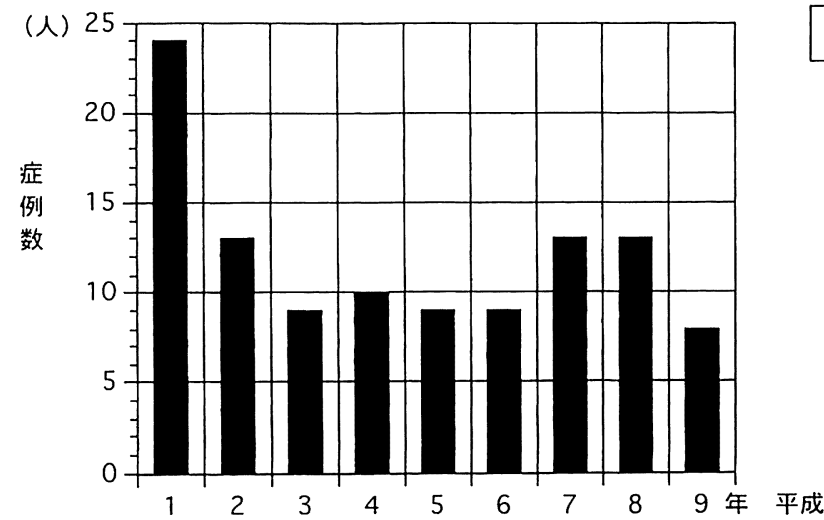

図 2 年度別治療頻度

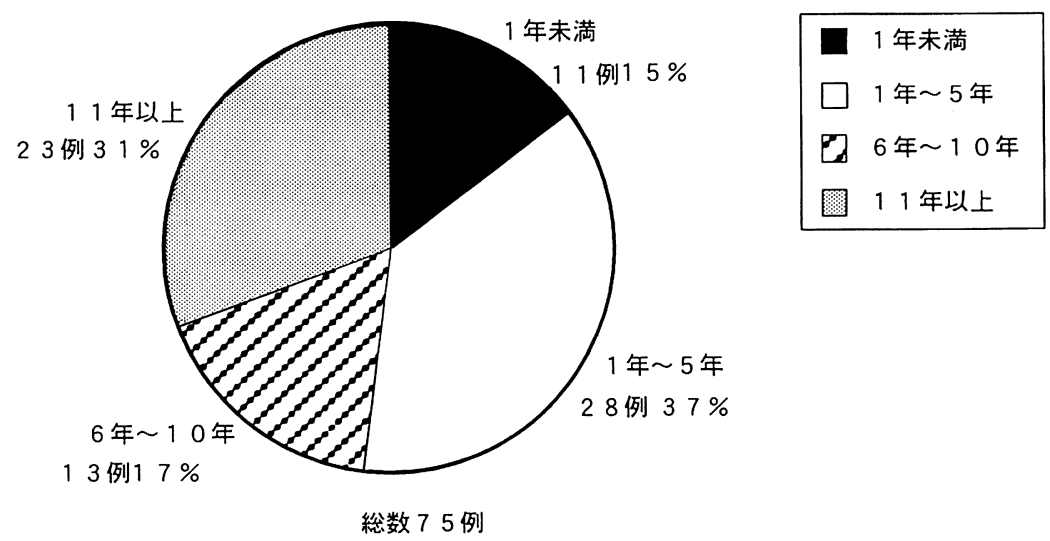

図 3 病悩期間 
表 1 上顎洞真菌症症例

\begin{tabular}{c|c|c|c}
\hline \hline 年齢(歳) & 性 別 & 罹患期間(年) & 主 訴 \\
\hline 52 & 女 性 & 0.5 & 不 明 \\
\hline 54 & 女 性 & 5 & 鼻 閉 \\
\hline 48 & 女 性 & 不 明 & 鼻出血
\end{tabular}

\section{考察}

今回検討した慢性副鼻腔炎108例の手術症例について は年齢分布は12〜72歳に及んだ.男性では壮年以降の手 術症例が，女性では10代，50代に多く手術を行っていた. 男女比は約 3 対 2 で男性に多かった．女性で20，30代に 減少しているのは出産育児などの社会的影響があるもの と考えられる．適切な手術年齢を考慮する際には上靧洞 手術によって引き起こされる顔貌を構成する上顎骨の変 化を十分考慮に入れなければならない，長船 ${ }^{1)}$ は小児慢 性副鼻腔炎手術の追跡調査を行い，非手術側にくらべて X線上骨発達異常をみたとしている．高橋2) は小児慢性 副鼻腔炎では自然治癒の可能性があり，かつ上顎洞は10 代後半で完成するので，手術はそれ以降がよいとしてい る.当科としても上顎洞の発達段階での手術はできるだ けさけ，できれば高校生になってから手術を行らのが適 当と考えている.
表 2 中高生に扣いての根治手術症例

\begin{tabular}{|c|c|c|c|c|}
\hline 手術時年齢 & $\begin{array}{c}\text { 罹患期間 } \\
\text { (年) }\end{array}$ & 鼻閉 & 鼻汁 & $\begin{array}{l}\text { その他 } \\
\text { の症状 }\end{array}$ \\
\hline \multicolumn{5}{|l|}{ 男 性 } \\
\hline 12 & 3 & あり & & \\
\hline 13 & 10 & あり & & \\
\hline 15 & 1 & あり & あり & \\
\hline 15 & 2 & あり & & \\
\hline 16 & 10 & あり & & \\
\hline 16 & 1 & あり & & \\
\hline 17 & 1 & あり & あり & \\
\hline \multicolumn{5}{|l|}{ 女 性 } \\
\hline 13 & 6 & あり & & 嗅覚障害 \\
\hline 14 & 4 & あり & & \\
\hline 14 & 10 & あり & あり & \\
\hline 16 & 5 & あり & & 頭 痛 \\
\hline 16 & 10 & あり & & 嗅覚障害 \\
\hline 17 & 5 & あり & & \\
\hline 18 & 10 & あり & & 嗅覚障害 \\
\hline 18 & 3 & あり & & \\
\hline
\end{tabular}

3 例の上顎真菌症にたいしても根本手術が行われてい る.

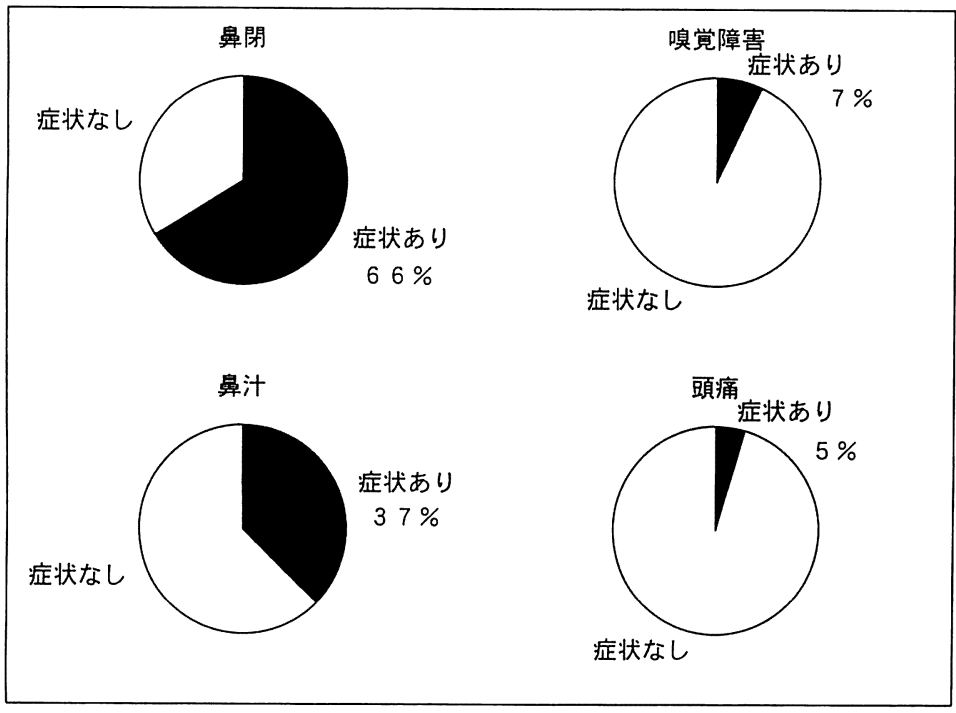

症状あり 症状なし

図 4 症状の分類

総数 83 例.

複数の主訴を有すものはそれぞれの項目を別々に集計した。 
病悩期間については平均 5 年と比較的長い例が多かっ た. 10 年以上，なかには 30 年以上といら症例も数例あっ た. 仕事家事が一段落したころ受診し手術となったもの と考える.多くは数年間保存的に治療したが症状がとれ なかったあとの手術が多いと思われた。

手術前の自覚症状の主なものは鼻閉, 鼻汁であった. 金田ら ${ }^{3)}$ の報告では，篩骨洞病変も含まれているので厳 密な比較はできないが鼻閉 $(91 \%)$, 鼻漏 $(68 \%)$, 後鼻漏 (43\%)，嗅覚障害 (43\%)，頭重感 (23\%)であった.

学童期の手術の検討では, 最少年龄12歳であったが, この児は，16力月の間に 3 回鼻茸摘出術を受けたが再発 してきた難治例であった.

今回の検討には鼻茸切除術のみ行った症例は含まれて いないが，症状緩和のためには選択肢の一つとなりら る).

$$
\text { まとめ }
$$

(1)過去 9 年間の上顎洞根本手術をらけた108例を報告 した.
(2)男性68例，女性40例，平均年齢42歳であった.

(3)主訴は鼻閉が約 3 分の 2 の症例にあり, 鼻汁, 嗅覚 障害, 頭痛が続いた。

(4)病悩期間は平均 5 年で, 10 年以上の症例も 23 例存在 した。

(5)学童期の手術につき検討した.

\section{参考文献}

1）長船宏隆：小児副番腔手術の追跡調查. 耳展 $17: 75 \sim 81$, 1974.

2) 高橋 良: 慢性副鼻腔炎の自然的变動とくにその不安的に ついて. 耳展 $9: 367 \sim 381,1996$.

3 ）金田宏和, 鶴田至宏, 田中 治, 他：慢性副鼻腔炎根治術 施行例の臨床統計.耳鼻臨床 補37：114〜120, 1990.

4) 栫 博幸, 西川和明, 喜多村健, 他: 当科飞打ける鼻副鼻 腔手術の臨床統計. 耳鼻臨床 補59：35～42, 1992.

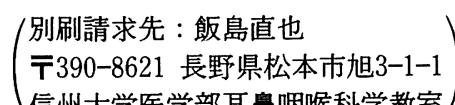

